\title{
Phonics and Semiotics for Early Intervention
}

\author{
Lucia Y. Lu \\ Valdosta State University \\ 1500 N. Patterson St. Valdosta, GA 31698, U.S.A. \\ E-mail: lylu@valdosta.edu
}

\begin{abstract}
Clay's Reading Recovery has been one of the most effective one-to-one tutorial sessions. To make the daily lesson more interesting and fully engage the at-risk readers, the author modified Clay's Reading Recovery Program by conceptualizing phonics and semiotics into early intervention. In this case study, three at-risk first graders formed an authors' circle and constructed a variety of signs such as drawing, role playing, storytelling, invented spelling, and kinesthetic movements to expand their potential for understanding and communicating their transaction with the text. The research results positively reflect that phonics and semiotics-based early intervention foster the at-risk early readers' break through the bottleneck to literacy and ensure them on the right track to educational success.
\end{abstract}

Keywords: At-risk early reader, Early intervention, Phonics, Reading Recovery, Semiotics, The Authoring Cycle Phonics and Semiotics for Early Intervention

\section{Introduction}

"I don't want to read!"

The reading facilitator gave each student a story book, and invited, "Lauren, could you read the title?"

Lauren stated, "I don't want to!"

The reading facilitator asked, "Megan, you read it?"

Megan exclaimed, “I don't want to, and I don't like the pictures!"

The reading facilitator asked Kris, "How about you? Kris?"

Kris said, "No! Thank you!"

Eric walked around and did not reply to the reading facilitator's calling.

The same story happened every morning when the author observed the interaction between the reading facilitator and her 4 at-risk readers for three days before a university-affiliated elementary school, in a small town in the Midwest, planned to implement reading intervention in the first grade in the coming semester.

\subsection{Background of the Study}

The author and two parents were recruited by the PTA and were trained to take part in the program. First, they listened to individual student read weekly throughout the fall semester to evaluate the first graders' oral reading proficiency. On average, three to four students in each classroom were labeled as low proficiency and were placed into the reading intervention program in the spring semester.

The author observed her 3 at-risk readers in their classrooms for one week as a "kidwatcher" (Goodman \& Goodman, 1996) in the beginning of the spring semester. She obtained some basic information from her observation and from their classroom teachers. These 3 at-risk readers were from middle socioeconomic families and were characterized with low motivation, little confidence, less engagement, were very restless, and were labeled with reading and writing disability. Moreover, they always complained that the books were "boring" and were not of any interest to them.

\subsection{Literature Review}

Based on recent US National Adult Literacy Survey released on December 15, 2005, there are 55\%, or 30 million of US adults age 16 and older, displayed Below Basic Prose Literacy with no more than the most simple and concrete literacy skills. That means, they are unable to read or write anything above the third grade levels. The cover page of Time magazine on April 17, 2006 posted a special report entitled "Dropout Nation" saying that $30 \%$ of American's high school students left school without graduating, and there are not enough blue-collar jobs to save them from poverty (Thornburgh, 2006). One of the five things schools can do is to teach reading early, since third graders who cannot read well begin a downward spiral of frustration, and early literacy programs keep them ahead off the game. The dropouts who went back to school are doing so for basic reading and math (Thornburgh, 2006). An official report revealed that $20 \%$ of the first and second grade students in the 
public school setting have reading/writing difficulties; early literacy can be accountable for the situation. If early intervention were not provided immediately at the school setting, those at-risk early readers would become the future dropouts from schools, and their problems would soon go beyond reading.

\subsection{Objective}

Clay's Reading Recovery has been one of the most effective one-to-one interventions (Fullerton \& DeFord, 2001). To make early intervention program more interesting and motivate the at-risk early readers to learn, the author modified Clay's Reading Recovery by conceptualizing phonics and semiotics theories into the school intervention program. She arranged the 3at-risk early readers to form an authoring circle and invited them to construct multiple sign systems such as drawing, singing, dancing, invented spelling, storytelling, role playing, and kinesthetic movement to extend their potential for communicating their transaction with the text. The goals are (a) to prevent the at-risk early readers from future school dropout, (b) to help them break through the bottleneck of literacy, and (c) to make them independent readers as well as critical thinkers and get on the right track to school success.

\section{Theoretical Framework}

\subsection{Phonics}

The author believes that literacy skills learned in a natural way through authentic life experience stories can be more effective (Dow \& Baer, 2003). She started her weekly lesson with language experience stories, embedding phonics instruction like alphabetic principle, phonemic awareness, decoding and encoding skills (Savage, 2007) daily. The at-risk early learners observed the transition from print to oral language when they struggled to read aloud in terms of decoding, and from oral language to print when they dictated to the reading facilitator in terms of encoding. The instruction of phonics is more effective when it is embedded in the natural language rather than in isolation. For example, the author used The Cat in the Hat (Dr. Seuss, 1957) for the students to practice the decoding skill after the funny story.

\subsection{Semiotics}

Semiotics is the science of signs (Cunningham, 1992; Sebeok, 1991; 2001), and the literacy landscape that puts images, gestures, music, movement, animation, and other representational modes on equal footing with language (Siegel, 2006). Vygotsky proclaimed that semiotic emphasis on the use of signs brings with it a focus on meaning as central to human activity (Moll, 1997). The four components of semiotics are (a) signs - anything bears meaning; (b) semiosis - the construction of signs; (c) inference - reasoning of signs; and (d) reflexivity the reflection on the process of signs. Languages, arts, music, dance, drama, mathematics, cultural modes, etc. are signs or sign systems that humans created to mediate the world (Cunningham, 1992; Deeley, 1994). According to semiotics, a good language arts curriculum must be able to expand a learner's potential for understanding and communicating through a variety of signs, not only language (Gray, 2006; Hubbard, 1989; Leland \& Harste, 1994; Short, Kauffman, \& Kahn, 2000; Suhor, 1992). When readers are striving to communicate and construct different sign systems to interpret their understanding of the text, and since the connection between different sign systems does not exist a priori, it would be an "anomaly" to learners (Siegel, 1995). To Peirce, anomalies which learners encounter in their daily lives drive the process of inquiry into the endless cycle of inference (Cunningham, 1992) (See Figure 1): abduction (generating hypotheses), deduction (testing hypotheses), and induction (accepting, rejecting or modifying the previous hypotheses). Learners should be provided with opportunities to become actively involved in the construction of knowledge through these reasoning processes. In education, the shift from a knowledge transmission model to an inquiry-oriented model of teaching and learning can be achieved through the process of inference, or reasoning, in a social context (Siegel, 1995).

\subsection{The Authoring Cycle}

Clay's Reading Recovery is a typical one-to-one tutorial session designed for individual instruction (Clay \& Cazden, 1997), but the author believed that social interaction provides the opportunity for children to learn more about the world (Goodman \& Goodman, 1997; Holiday \& Hasan, 1985). Additionally, there is growing evidence that collaborative learning between peers, regardless of ability, activates the zone of proximal development (Tudge, 1997). The author implemented "The Authoring Cycle" (Short, Harste, \& Burke, 1995) (See Figure 2) as a framework for her Semiotic-Based Early Intervention. Usually, there are two to six students seated in the authors' circle for social interaction. 


\section{Design of Research}

This research was designed to be a case study, a naturalistic inquiry focused on an individual reader's uniqueness. The 3 at-risk first graders engaged in this semiotic inquiry were pseudonymous.

The author and her 3 at-risk first graders seated in a circle as the "authors" circle" daily from 9:00 am - 9:30 am in the school media center. They were expected to complete their reading intervention within twelve weeks in the spring semester.

Clay's theory of reading and writing requires readers to use four cues: semiotic, syntactic, visual and phonological (Clay \& Cazden, 1997). Her form of Vygotskian mediation integrates the semiotic codes of oral language and English orthography, plus world knowledge into the complex operations of reading and writing (Clay \& Cazden, 1997). The author did not change Clay's form of mediation; instead, she modified it by adding signs like drawing (Gray, 2006; Hubbard, 1989; Leland \& Harste, 1994; Short, Kauffman, \& Kahn, 2000; Suhor, 1992), storytelling, role playing, sentence making, invented spelling (Gentry, 2000; Laminack \& Wood, 1996), VAKT (Rasinski \& Padak, 2000) and Kinesthetic movement (Gardner, 1990) for phonemic awareness (Wilson, Hall, Leu, \& Kinzer, 2001), inference (Cunningham, 1992) for critical thinking, running records (Clay, 1994), miscue analysis (Goodman, Watson, \& Burke, 2005) and peer's cross correction as the alternate assessment tools.

Daily Lesson for A Phonics- And Semiotic-Based Early Intervention

(Lu, 1998; 2005)

\begin{tabular}{|c|}
\hline Day I - Story \\
\hline $\begin{array}{l}\text { 1. The reading facilitator gives students a topic related to the selected book and their life experiences, } \\
\text { 2. the facilitator invites students to tell stories about their life experiences and dictate to the reading } \\
\text { facilitator, } \\
\text { 3. the facilitator helps each student speak out a sentence from his/her own story, and the facilitator } \\
\text { handwrites each sentence on a long strip, and }\end{array}$ \\
\hline $4 \quad$ students take turns reading the book, and the facilitator locates the students' unknown words. \\
\hline
\end{tabular}

Day 2 - Drawing \& Sentence Making

1. The facilitator gives each student a note pad and invites them to draw pictures on the pads based on their stories,

2. the facilitator presents to each student his/her sentence which the facilitator hand wrote on the previous day, and cuts the sentence into one-word chunks in front of the students,

3. the facilitator asks each student to assemble the chunks into a sentence, and students are also invited to assemble their peers' sentences, and

4. the facilitator asks each student to hand write his/her own sentence on the note pad.

Day 3 - Game for Phonemic Awareness

1. The reading facilitator reads new words from the book, and challenges students to listen and to use the magnetic letters to make words, to break words, and to make words with similar sounds (onsets or rimes),

2. the facilitator models the game of phonemic awareness,

3. students think about kinesthetic movements to play the game of phonemic awareness, and

4. the facilitator asks students to take turns reading the book.

Day $4-$ Assessment

The reading facilitator asks each student to read aloud the book, the facilitator marks miscues and keeps running record for each student's oral reading proficiency, the other students prepare to share their artifacts with drawing and hand writing, and the facilitator informs the students that their stories and drawings will probably be published as the reading material in the future. 
1. The reading facilitator uses running records to check students' progress of their oral reading proficiency,

2. the facilitator analyzes the miscues which are prevalent in every reader, and 3. the facilitator selects books fitting students' interests and reading level for next week.

\section{Discussion}

\section{1 Life Experiences}

Life experience is the starting point of the "Authoring Cycle" (Short, Harste, \& Burke, 1995) as the framework of this early intervention. Based on the author's personal conversation with her 3 at-risk first graders, she obtained some basic information about their interests such as pets, friends, relatives, biking, camping, vacation, field trip, birthday parties, TV programs, etc. The books she selected were related to her 3 students' interests and life experiences (Rosenblatt, 1989). Before they read the book, the author invited her 3 at-risk early readers in the authors' circle to take turns sharing their life experiences related to the topic of the selected books.

\subsection{Language Experience Approach (Ashton-Warner, 1965)}

The 3 at-risk readers dictated to the author when they were invited to take turns telling stories related to the topic of the selected book, the dictation is actually the reader's story. For example, the first book she selected was Camping (Hooker \& Biddle, 1998). The book was labeled as level 9 with 64 running words. She selected this book because of its interesting topic that related to her students' life experience of camping, rather than their reading level.

Before she passed the book Camping to her students on Monday, the first day of the week, the author greeted them and asked, "Kris, I know you and your family went camping last summer. How did you like it? Tell us the story!"

Kris was so excited to accept her invitation and told his story: "Last summer when my dad was on vacation, we decided to go camping. My dad rented an RV and he drove it to a campground near Lake Superior. I helped my dad build a tent with a zipper door, and I helped my stepmother build a campfire. My dad and I fished in the lake, and my stepmother baked the fish on the campfire. The fish was very crunchy. I liked it."

Gradually, Megan and Lauren stopped their side-talk and paid attention to Kris' story. Kris' eyes were bright when he told the story.

Lauren asked, "Did you see any shark in the beach?"

Kris laughed and answered, "No! Silly! Sharks live in the ocean, not in the lake."

Megan asked, "Did your dog go with you?"

Kris answered, "Sure, but he (it) is afraid of water, he (it) watched us swim!"

The author then invited Megan to tell her story and Megan was excited too. She said, "My family and I went camping too. Petty, my puppy, went with us, but a hermit crab pinched her on her leg."

Lauren was very nervous and asked, "Was Petty hurt?"

Megan said, "Not really! My dad got rid of the hermit crab."

Lauren asked, "May I go camping with you next time, Megan?"

Megan answered, "No, cause (because) our tent is small! We had to put the dogs in the car."

Kris commented, "I think you can sleep in your own tent, Lauren."

According to their conversation, the 3 at-risk early readers enjoyed telling and listening to stories. They did not interrupt each other, but they paid attention to the story, and helped to solve Lauren's problems.

\subsection{Drawing}

On the second day, the author passed a box of crayons and a note pad to each student, and invited them to draw a picture of camping; they did so. When the author invited the 3 readers to share their drawings of "camping", Kris was the first student to share his drawing.

Megan commented, "Hey, Kris, where is the campfire on your picture, cause (because) you told us about the campfire and where did your stepmother put the fish?" 
Kris said, "Oh, I did not have time to draw the campfire." He asked for crayons to draw the campfire near the tent, later adding a fish on the net above the campfire (See Figure 3).

It was obvious that Megan paid attention to Kris' storytelling on the previous day, and she asked Kris questions about the fish and the campfire which he missed in his drawing.

Megan was the second student to share her drawing, "This is my Petty, and this is the hermit crab that pinched Petty." (See Figure 4).

Lauren was the last student to share her drawing, "This is my tent, this is me, and this is Megan; I like to go camping with Megan.” (See Figure 5).

Megan smiled and said, "Don't forget your tent and your sleeping bag." Both Lauren and Megan listened to Kris' suggestion.

Kris nodded, "That's right! Lauren, remember your own tent and sleeping bag."

The same life experiences made them good friends and they discovered they would like to help one another

instead of interfering with one another. Drawing (Gray, 2006; Hubbard, 1989; Leland \& Harste, 1994; Short, Kauffman, \& Kahn, 2000; Suhor, 1992) is one of the sign systems that the students created to construct meaning (Cooper \& Kiger, 2009; Cornett, 2007), to transact (Rosenblatt, 1989) their life experience with the world of the text; and the author integrated $(\mathrm{Lu}, 2008)$ into the reading, writing, and thinking (Short, Kauffman, \& Kahn, 2000) of this semiotic-based intervention program.

\subsection{Sentence Making}

On the second day, after students shared their drawings, the author presented their sentences which she handwrote for them on long strips of paper, and then she cut up each sentence into many one-word chunks in front of the students. Later, she invited each student to put his/her own chunks together.

Since the students knew their own sentences and their peers', they were happy to assemble their own sentences and offered to assemble their peers' sentences from the word chunks. This activity implicitly helps students learn the sentence structure. In this intervention program, each student in the authors' circle learned three different sentence structures each week.

\subsection{Inventive Spelling}

Later, the author invited the students to handwrite their sentences on the note pad. Instead of commenting that their sentences were too short, their handwriting was illegible, their letter formation was bad, their spellings and capitalization were wrong, the author would like to say that their writings are meaningful. Passed through the authors' circle (Short, Harste, \& Burke, 1995), the students shared their drawing and writing, and tried to correct letter formation for each other though the author did not ask them to do the correction. The words that the students invented are not on the spelling list of the first grade. Since most students enter school with a relatively large oral vocabulary - perhaps 5,000 words - and a quite small reading vocabulary (Graves, Watts-Taffe, \& Graves, 1999), the author encouraged them to sound out, or to articulate (Gentry, 2000; Laminack \& Wood, 1996; Savage, 2007) the words, they needed to construct meanings (Cooper, \& Kiger, 2009). For example, Kris wrote his sentence as "I like to go camping and fishing." (See Figure 3), Megan's sentence was: "The crab is pinching my dog." (See Figure 4), and Lauren wrote, "I like to go camping with Megan." (See Figure 5).

\subsection{Direct Reading}

Later, the author told her students, "You all had wonderful experiences with camping. Now, let's see other people's story about camping!" And she invited them to take turns read aloud the small book Camping. Nobody rejected her! When they were reading, the author located the unknown words that would be the new vocabulary words they should learn that week. The author believed that reading is an act where readers construct meanings as they bring information already in their heads to the messages that the authors have encoded (Watson, 1996). Reading is not a simply random, uncontrolled behavior. Listening to students read uninterrupted texts provides a "window on the reading process" (Goodman \& Goodman, 1996; Goodman, Watson, \& Burke, 2005), and instruction and assessment of reading are an ongoing process when reader, text, task, technique and context, the five variables of reading, keep interacting with one another (Walker, 2000).

\subsection{Word Analysis and Kinesthetic for Phonemic Awareness}

When the author located the words that were unknown to her students, she included the kinesthetic movements (Gardner, 1985) for the game of phonemic awareness (Wilson, Hall, Leu, \& Kinzer, 2001). The words on the top 
line were those the author picked from the book Camping, and she challenged her students to say words with similar sound (rime) on the second and third lines:

$\begin{array}{llllllll}\text { 1. } & \text { cat } & \text { ride } & \text { path } & \text { bike } & \text { park } & \text { pool bug } & \text { toast } \\ \text { 2. } & \text { hat } & \text { side } & \text { bath } & \text { like } & \text { dark } & \text { fool hug } & \text { coast } \\ \text { 3. fat } & \text { hide } & \text { math } & \text { Mike } & \text { Mark } & \text { cool mug } & \text { boast }\end{array}$

Later, the author demonstrated the first group of words with the kinesthetic movements. For example, when they heard "cat", they had to say, "m-e-o-w", when they heard "hat", they had to touch their heads, when they heard "fat", and they had to figure their bodies.

For the second, third, and fourth group, the author invited her 3 readers to take turns acting as the leader, teaching us to use kinesthetic movements to signal the words they heard.

Kinesthetic movements are their favorite activity which made word analysis interesting, captured their attention when they had to use their audio-visual acuity to discriminate the sounds and letters, and thought about kinesthetic movements to play the game. Most importantly, they learned the relation between "letter" and "sound" (Menn \& Stoel-Gammon, 2001). This is a whole-to-parts phonics instruction building on what children already know to help them learn more (Moustafa, Maldonado-Colon, 1999). The author remembered that she could not dismiss them; even the clock on the wall said it was 9:30 a.m.

\subsection{Inference for Problem Solving}

The problems that happened in the authors' circle are "anomalies" that stimulated the learners to think (Cunningham, 1992) and to exercise their reasoning: (a) Abduction (generating hypotheses, (b) Deduction (testing hypotheses) and (c) Induction (accepting, rejecting or modifying previous hypotheses) to solve the problems. For example, when they read the other book Lost at the Fun Park (Smith,1997), the students shared their stories about how they got lost in the state fairground, in the mall, in the campground when they were little, and tried to think about different ways to help the young children who get lost. Additionally, they learn how to work collaboratively by listening to others, speaking out in their own voices, respecting others, and by negotiating if they were very different. They were no longer the naughty students interrupting each other; instead, they were fully engaged in the authors' circle.

\subsection{Weekly Assessment: Running Records, Miscue Analysis and Students'Peer Cross Correction}

The weekly assessment was conducted in terms of oral reading accuracy through the running records (Clay, 1994) and miscue analysis (Goodman \& Goodman, 1996; Goodman, Watson, \& Burke, 2005) on the fourth day.

4.9.1 Running records. "Running records" are taken by dividing the number of errors students make in oral reading by the number of total different running words. The reading level of the book would probably be too easily if the accuracy percentage is more than $95 \%$, and too hard if the accuracy percentage is less than $90 \%$. Usually, the reading facilitators use this percentage as a criteria to select the reading materials for the coming week. There is an abundance of early reading materials in the media center of that school, but each publisher used its own leveling system (Rog \& Burton, 2001). This is the reason why it is sometimes hard to match texts and readers' level.

4.9.2 Miscue analysis. "Miscues" are the unexpected responses cued by readers' linguistic or conceptual cognitive structures that would change, disrupt, or enhance the meaning of a written text (Goodman \& Goodman, 1996; Goodman, Watson, \& Burke, 2005). The author found that her students" "errors", or "mistakes", in orally reading written texts were "high quality ones" (Goodman, 2000), that means, the errors or mistakes did not really change the meanings of the context. For example,

Text: $\quad$ My family loves to go camping.

Some read, "My family likes to go camping."

Text: $\quad$ We play at the pool and splash each other.

Some read, "We play at the swimming pool and splash water each other."

Text: We ride bikes on the bike path.

They read, "We ride our bikes on the bike road."

Text: We have a campfire and the toast marshmallows.

They read, "We built a campfire and toasted the marshmallows." 
Text: We scare each other at night on the way to the bathroom.

They read, "We scare each other at midnight on the way to the bathroom."

The combination of running records and miscue analysis demonstrated that those children kept maintaining the oral reading proficiency degree above $96 \%$ over the weekly increasing difficult texts.

4.9.3. Peer's Cross-Correction. It was a surprise that the at-risk early readers offered to correct their peers' incorrect pronunciation when they read aloud, and their peers' spelling or formation of letters when they wrote. This activity was not in the design, but it happened in a very natural way! The peers graciously accepted this kind of cross-correction without the feeling of being offended.

4.10 Trade Books across the Curriculum and Make Reading Fun.

To make reading fun, when the author selected the Beginner Books for the reading intervention, she followed these basic principles (Levine, 2001): showing relationship between pictures and text, introducing written words using visual clues as to their meanings, involving words that commonly exist in a child's world and are repeated whenever possible, connecting to her 3 at-risk readers' life experience, attracting their interest, bearing simple and straightforward plots, integrating (Lu, 2008) across the curriculum to benefit the art-risk readers with concepts in math, science and social studies:

Math: A Chair for my Mother (Williams, 1984). A child and her grandmother save dimes to buy a comfortable armchair for the waitress mother after all their furniture is lost in a fire.

Science: Afternoon on the Amazon. Magic Tree House \#6 (Osborne, 1995). The adventure of Jack and Annie about the rain forest.

Social Studies: Mummies in the Morning (Osborne, 1993). The exploration of Jack and Annie about the ancient Egypt.

Language: The Cat in the Hat and books by Dr. Seuss for the practice of decoding and encoding skills after the funny story.

\subsection{Differentiated Instruction in Reading \& Writing (Chapman \& King, 2003)}

Diversity can be defined as age, gender, interest, personality, intelligences, behavior, and life goals (Chapman \& King, 2003). In this case study, the author paid more attention to students' interests rather than their reading levels, and motivated their interests in reading and writing.

\subsection{Storyteller, Authors and Illustrators of Children Literature}

Later, the author showed the students the typed stories they dictated to her and told them their stories might be collected with their drawings and published as reading materials for the reading intervention program in the future. Her 3 at-risk first graders were very surprised. The semiotic inquiry into early intervention made the at-risk early readers storytellers, authors, and illustrators of children's literature.

\section{Conclusion: Get on the Right Track to School Success}

Due to the discovery of their different multiple intelligences (Gardner, 1990), the at-risk early readers picked up their self-esteem when they went back to their classrooms, worked collaboratively with regular school students. Their motivation in learning was activated when the author saw them voluntarily select books to read without worrying about their reading level (Rog, \& Burton, 2001), enthusiastically write and draw their stories, happily use magnetic letters for word making and breaking, and actively engage in brainstorming to solve problems or to predict the story. Their self-monitoring rate in reading increased, and peers' cross-correction in the author's circle occurred. Ten weeks later, they were able to work in the regular classroom setting, and were withdrawn from the reading intervention program. They did not wait for 12 weeks as designed in the beginning. The socio-semiotic inquiry in early intervention helped the 3 at-risk early readers pass through the bottleneck to literacy, prevent them from becoming the future school dropouts, make them independent readers and critical thinkers, and start on the right track to school success.

\section{References}

Ashton-Warner, S. (1965). Teacher. New York: Simon \& Schuster.

Chapman, C., \& King, R. (2003). Differentiated instructional strategies for reading in the content areas. Thousand Oaks, CA: Corwin Press, Inc.

Chapman, C., \& King, R. (2003). Differentiated instructional strategies for writing in the content areas. Thousand Oaks, CA: Corwin Press, Inc. 
Clay, M. M. (1994). Reading recovery: A guidebook for teachers in training. Hong Kong: Heinemann.

Clay, M. M. \& Cazden, C. B. (1997). A Vygotskian interpretation of reading recovery. In L. C. Moll (Ed). Vygotsky and education. (pp. 206-222). New York, NY: Cambridge University Press.

Cooper, J. D. \& Kiger, N. D. (2009). Literacy: Helping children construct meaning (6 ${ }^{\text {th }}$ ed.). Boston: Houghton Mifflin Company.

Cornett, C. E. (2007). Creating meaning through literature and the arts: An integration resource for classroom teachers ( ${ }^{\text {rd }}$ ed.). Upper Saddle River, NJ: Pearson Merrill Prentice Hall.

Cunningham, D. J. (1992). Beyond educational psychology: Steps toward an educational semiotic. Educational Psychology Review, 4, 165-194.

Deely, J. (1994). The human use of signs. London: Rowman \& Littlefield Publishers, Inc.

Dow, R. S. \& Baer, G. T. (2003). Self-paced phonics $\left(3^{\text {rd }}\right.$. Ed.). Upper Saddle River, NJ: Pearson Merrill Prentice Hall.

Fullerton, S. K. \& DeFord, D. E. (2001). Conversations before writing during reading recovery lessons: Negotiation or tug of war? In J. V. Hoffman, D. L. Schallert, C. M. Fairbanks, J. Worthy, \& B. Maloch (Eds.), National Reading Conference Yearbook, 50 (pp. 213-227). Chicago: National Reading Conference.

Gardner, H. (1990). Multiple intelligences: implications for art and creativity. In W. J. Moody (Ed.), Artistic intelligences (pp. 11-27). New York: Teachers College Press.

Gentry, J. R. (2000). A retrospective on invented spelling and a look forward. The Reading Teacher. 54 (3), 318-332.

Goodman, Y. M. (2000). Research implications of retrospective miscue analysis: struggling readers revaluing themselves and their reading. Paper presented at the $50^{\text {th }}$ National Reading Conference, Scottsdale, AZ.

Goodman, Y. M. \& K. S. Good (1996). To err is human: Learning about language processed by analyzing miscues. In S. Wilde (Ed.). Notes from a kidwatcher (pp. 94-116). Portsmouth, NH: Heinemann.

Goodman, Y. M. \& K. S. Goodman. (1997). Vygotsky in a whole-language perspective. In L. C. Moll. (Ed). Vygotsky and education. (pp. 223-250). New York, NY: Cambridge University Press.

Goodman, Y. M., Watson, D. J. \& Burke, C. L. (2005). Reading miscue inventory: From evaluation to instruction. ( $2^{\text {nd }}$ ed.). New York: Richard C. Owen Publishers, Inc.

Graves, M. F., Watts-Taffe, S. M. \& Graves, B. B. (1999). Essentials of Elementary Reading. Boston, MA: Allyn and Bacon.

Gray, E. C. (2006). Children's use of language and pictures in classroom inquiry. Language Arts 83 (3).227-237.

Harste, J. C., Short, K. G. \& Burke, C. (1988). Creating classrooms for authors. Portsmouth, NH: Heinemann.

Holiday, M. A. K. \& Hasan R. (1985). Language, context, and text: Aspects of language in a social-semiotic perspective. Victoria, Australia: Deakin University Press.

Hubbard, R. S. (1989). Authors of pictures, draughtsmen of words. Portsmouth, NH: Heinemann.

Jenkins, L. \& Baldi, S. (1999). The national adult literacy survey: An overview. Washington, D.C.: The National Center for Educational Statistics.

Laminack, L. L., \& Wood, K. (1996). Spelling in use. Urbana. IL: National Council of Teachers of English.

Leland, C. H., \& Harste, J. C. (1994). Multiple ways of knowing: Curriculum in a new key. Language Arts, 71, 337-345.

Levine, S. P. (2001). The importance of Dr. Seuss. San Diego, CA: Lucent Books.

Lu, L. Y. (2008). Semiotics for integrating geosciences into literacy in teacher education. In V. L. Akerson (Ed.) Interdisciplinary language arts and science instruction in elementary classrooms: Applying research to Practice (pp. 263-277). Mahwah, NJ: Lawrence Erlbaum Associations, Publishers.

Menn, L. \& Stoel-Gammon, C. (2001). Phonological development: Learning sounds and sound patterns. In J. B. Gleason (Ed.). The development of language. (5 ${ }^{\text {th }}$ ed.). (pp. 70-124). Boston, MA: Allyn \& Bacon.

Moll, L. C. (1997). Introduction. In L. C. Moll (Ed.). Vygotsky and education. (pp. 1-27). New York, NY: Cambridge University Press. 
Moustafa, M. \& Maldonado-Colon, E. (1999). Whole-to-parts phonics instruction: Building on what children known to help them know more. The Reading Teacher. 52 (5).

Rasinski, T. \& Padak, N. (2000). Effective reading strategies. Upper Saddle River, NJ: Prentice-Hall, Inc.

Rog, L. J. \& Burton, W. (2001). Matching texts and readers: Leveling early reading materials for assessment and instruction. The Reading Teacher, 55 (4). 348-356.

Rosenblatt, L. M. (1989). The transactional theory of the literary work: Implications for research. In C. R. Cooper (Ed.) Research response to literature and the teaching of literature: Points of departure (pp. 33-53).

Norwood, NJ: Ablex Publishing Corp.

Savage, J. F. (2007). Sound it out! Phonics in a comprehensive reading program (3 ${ }^{\text {rd }}$ ed.). Boston: McGraw-Hill.

Sebeok, T. A. (1991). Sign is just a sign. Bloomington, IN: Indiana University Press.

Sebeok, T. A. (2001). Global semiotics. Bloomington, IN: Indiana University Press.

Short, K. G. \& Burke, C. (1991). Creating curriculum. Portsmouth, NH: Heinemann Educational Books, Inc.

Short, K. G. Harste, J. C. \& Burke, C. (1995). Creating classrooms for authors and inquirers. (2 ${ }^{\text {nd }}$ Ed.). Portsmouth, NH: Heinemann.

Short, K. G., Kauffman, G. \& Kahn, L. H. (2000). "I just need to draw": Responding to literature across multiple sign systems. The Reading Teacher, 54 (2). 160-171.

Siegel, M. (1995). More than words: The generative power of transmediation for learning. Canadian Journal of Education, 20, 455-475.

Siegel, M. (2006). Rereading the signs: Multimodal transformations in the field of literacy education. Language Arts. 84(1). 65-77.

Suhor, C. (1992). Semiotics and the English language arts. Language Arts, 69, 228-230.

Thornburgh, N. (2006). Dropout Nation. Time. 167(16). 30-40.

Tudge, J. (1997). Vygotsky, the zone of proximal development, and peer collaboration: Implications for classroom practice. In L. C. Moll (Ed), Vygotsky and education. (pp. 155-172). New York, NY: Cambridge University Press.

Walker, B. J. (2000). Diagnostic teaching of reading (4 ${ }^{\text {th }}$ ed.). Upper Saddle River, NJ: Prentice Hall.

Watson, D. (1996). What exactly do you mean by the term kidwatching? In S. Wilde (Ed.) Making a difference (pp. 56-61). Portsmouth, NH: Heinemann.

Wilson, R. M., Hall, M., Leu, D. J. \& Kinzer, C. K. (2001). Phonics, phonemic awareness, and word analysis for teachers: An interactive tutorial ( $7^{\text {th }}$. ed.). Columbus, $\mathrm{OH}$ : Merrill Prentice-Hall.

\section{Children's book cited}

Dr. Seuss. (1957). The cat in the hat. New York: Random House.

Hooker, K., \& Biddle, B. (1998). Camping. Rocky River, OH: Kaeden Corp.

Osborne, M. P. (1995). Afternoon on the Amazon. Magic Tree House \#6. New York: Random House.

Smith, A., Mo, X., \& Wang, J. (1997). Lost at the fun park. New Zealand: Nelson Price Milburn Ltd.

Williams, V. B. (1984). A chair for my mother. New York: HarperCollins Publishers. 


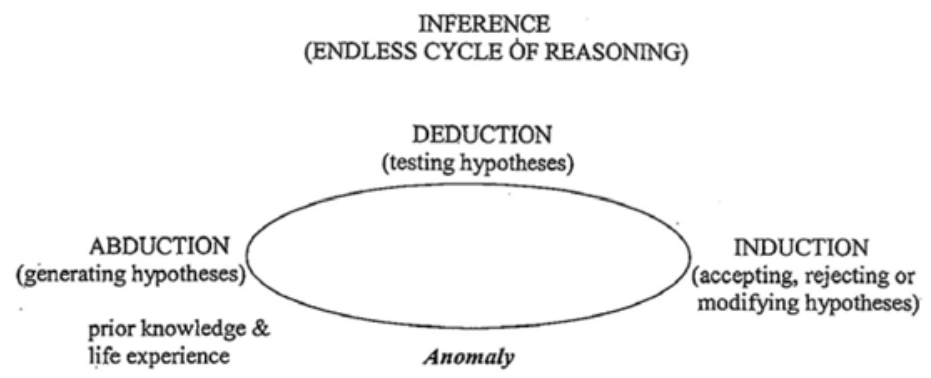

Figure 1. Inference (Cunningham, 1992, 1998)

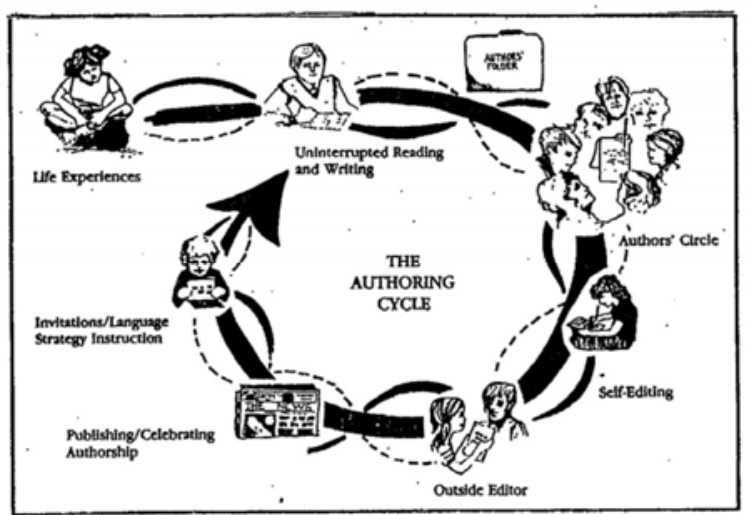

Figure 2. The Authoring Cycle (Short, Harste and Burke 1995)

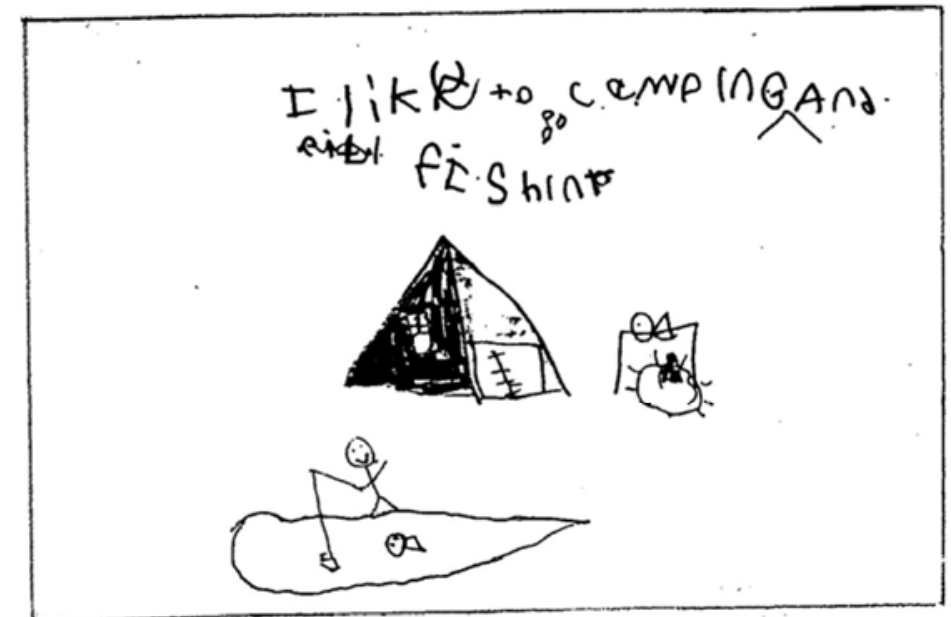

Figure 3.

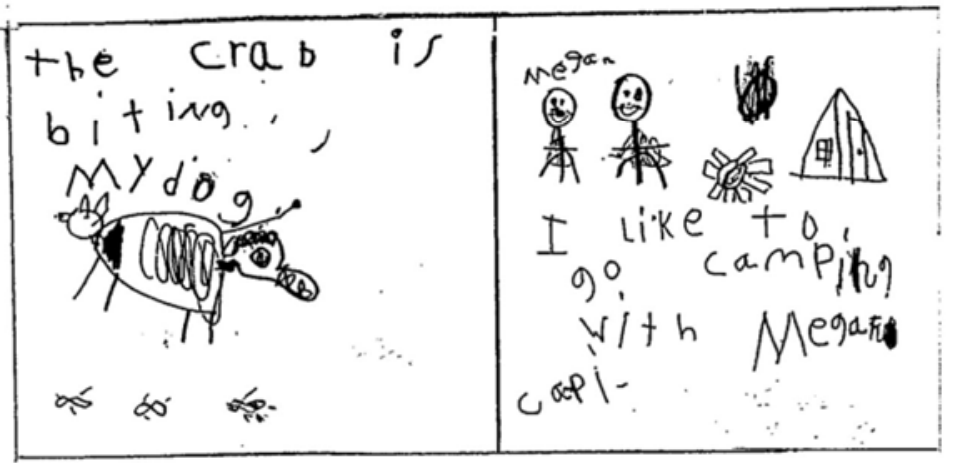

Figure 4

Figure 5. 